\title{
PEMETAAN KONDISI INTERNAL DAN EKSTERNAL UMKM TRANSPORTASI DENGAN MENGGUNAKAN ANALISIS SWOT DI SUMATERA UTARA
}

\author{
ARDIAN HIRAMAN AROTAMA ZEBUA1, IRWAN BUDIMAN1 \\ Program Studi Teknik Industri ${ }^{1}$, Universitas Prima Indonesial ${ }^{2}$ \\ ardianhiraman01@gmail.com, irwanb01@gmail.com
}

\begin{abstract}
Abstrak: Penelitian ini memfokuskan pada perusahaan jasa yang sedang mengalami penurunan jumlah penumpang pada wilayah Medan, Bandara Kualanamu Internasional, Siantar, Parapat, Sibolga, dan daerah Singkil. UMKM juga mengalami permasalahan yang diakibatkan beberapa factor yaitu: kekurangan armada, cara memasarkan kepada konsumen kurang, dan keterlambatan penjemputan konsumen. Penelitian ini bertujuan untuk mengetahui posisi perusahaan dalam Matriks IFAS dan EFAS serta program kerja prioritas. Metode yang dipakai dalam penelitian ini adalah analisis SWOT adalah metode perencanaan strategis yang digunakan untuk mengevaluasi kekuatan (strengths), kelemahan (weaknesses), peluang (opportunities), dan acaman (threats) dalam suatu proyek atau spekulasi bisnis. Hasil analisis SWOT menunjukkan bahwa perhitungan Matriks IFAS dan EFAS diperoleh hasil IFAS lebih tinggi daripada EFAS dan skor tertinggi terdapat pada Strengths sebesar 2,0667.
\end{abstract}

Kata kunci : Strategi, SWOT Analysis, Balanced Scorecard, QSPM 


\section{PENDAHULUAN}

Strategi dalam sebuah perusahaan adalah suatu gambaran tentang kondisi keuangan suatu perusahaan yang dianalisis dengan alat-alat keuangan, sehinggadapatdiketahui mengenai baik buruknya keadaan keuangan suatu perusahaan yang mencerminkan prestasi kerja dalam periode tertentu. Manajemen strategis merupakan proses penetapan misi, visi, dan tujuan organisasi, serta pengembangan kebijakan dan program pelaksanaan untuk mencapainya (Assauri, 2016).

Penelitian mengenai pengembangan strategi pernah dilakukan oleh William F. Glueckdan Lawrence R Jauch, (2015). Strategi dikembangkan dengan menggunakan Metode SWOT. Tujuan yang diharapkan dari strategi tersebut adalah untuk merumuskan suatus trategi perusahaan, seorang manajer harus mengetahui kemampuan, keterbatasan dalam memilih strategi perusahaan. Strategi yang diusulkan yaitu untuk mimilih strategi tersebut yang andal, yang disesuaikan dengan peluang, ancaman, kekuatan, dan kelemahan perusahaan.

Adapun penelitian lain tentang pengembangan strategi pernah dilakukan oleh Thomas L. Wheelendan David Hunger (2017). Pengembangan strategi dilakukan dengan Metode Balanced Scorecard. Strategi yang diperoleh yaitu perumusan, pelaksanaan, evaluasi.

Sebelum melakukan pengembangan strategi perusahaan secara tepat, maka perlu diketahui peta kondisi internal dan eksternal perusahaan sehingga strategi yang disusun akan tepat menggambarkan kondisi yang dibutuhkan perusahaan.

SWOT adalah metode perencanaan strategis yang digunakan untuk mengevaluasi kekuatan (strengths), kelemahan (weaknesses), peluang (opportunities), dan acaman (threats) dalam suatu proyek atau spekulasi bisnis.

Balanced Scorecard adalah suatu metode untuk pengukuran dan penilaian kinerja suatu perusahaan dengan mengukur empat perpektifyaitu: Keuangan, pelanggan, proses bisnis internal, pembelajaran dan pertumbuhan.

UMKM sedang mengalami penurunan jumlah penumpang pada wilayah Medan, Bandara Kualanamu Internasional, Siantar, Parapat, Sibolga, dan daerah Singkil. Akibat munculnya pesaingpesaing baru yang mengakibatkan jumlah konsumen bisa memilih layanan jasa transportasi lainnya.

UMKM yang ditimbulkan berdasarkan beberapa factor yaitu: kekurangan armada, cara memasarkan kepada konsumen kurang, dan keterlambatan penjemputan konsumen yang disebabkan oleh lalulintas padat pemungkiman yang semakin luas. UMKM tetap berusaha memberikan pelayanan yang terbai kselama 24 jam.

Dalam penelitian ini digabungkan metode SWOT dengan Balanced Scorecard untuk memperoleh hasil yang baik. Peta kondisi Internal dan eksternal akan menggunakan matriks IFASEFAS.

\section{METODOLOGI PENELITIAN}

Penelitian ini dilakukan di salah satu UMKM Transportasi di Provinsi Sumatera Utara. Pada penelitian ini, digunakan sampel sebanyak 3 orang dari total 7 orang. Teknik sampling yang digunakan adalah metode purposive sampling. Sampel dipilih berdasarkan respon dari tim managemen UMKM.

Adapun kerangka konseptual yang digunakan adalah dengan menganalisis kondisi perusahaan dengan menggunakan metode SWOT yang meliputi: kekuatan (strengths), kelemahan (weaknesses), peluang (opportunities), dan acaman (threats) dalam suatu proyek atau spekulasi bisnis. Setelah memperoleh informasi tentang kondisi perusahaan kemudian memberikan pembobotan atas strategisstrategi yang dikembangkan dalam mengetahui peta kondisi internal dan juga eksternal perusahaan, kemudian peneliti menyebarkan kuisioner terhadap sampel yang menjadi objek dalam penelitian ini dengan tujuan untuk memperoleh data tentang penilaian bobot dan tingkat kepentingan dari kusioner yang di sebarkan, setelah memperoleh hasil dari strategi-strategi yang dikembangkan kemudian melakukan perhitungan matriks IFAS dan EFAS, perhitungan ini dilakukan untuk memperoleh hasil peta kodisi internal dan juga peta kondisi eksternal dari perusahaan.

Hasil perhitungan dari matriks IFAS dan EFAS dalam penelitian ini yang merupakan kondisi aktual dari perusahaan. Hasil ini kemudian menjadi suatu landasan bagi peneliti dalam membuat suatu pemodelan matriks IFAS dan EFAS dengan fungsi untuk merepresentasi realita perusahaan dan menjadi 
suatu starategi baru dalam mengembangkan perusahaan kearah yang lebih baik serta mendukung visi dan misi perusahaan.

\subsection{Flowchart Penelitian}

Flowchart penelitian ini dapat dilihat pada gambar 2.1.

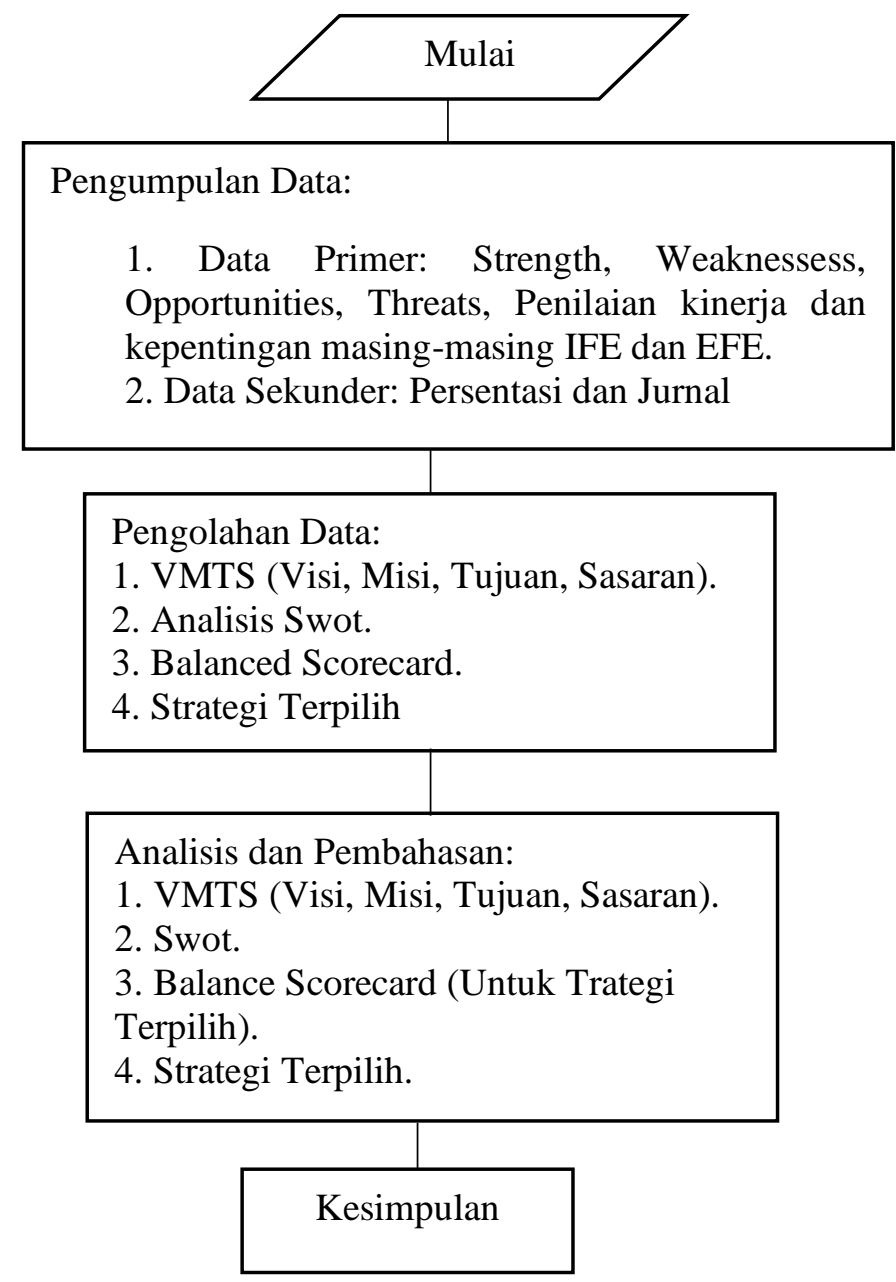

\subsection{Kerangka Konseptual}

Kerangka konseptual dapat dilihat pada Gambar 2.2:

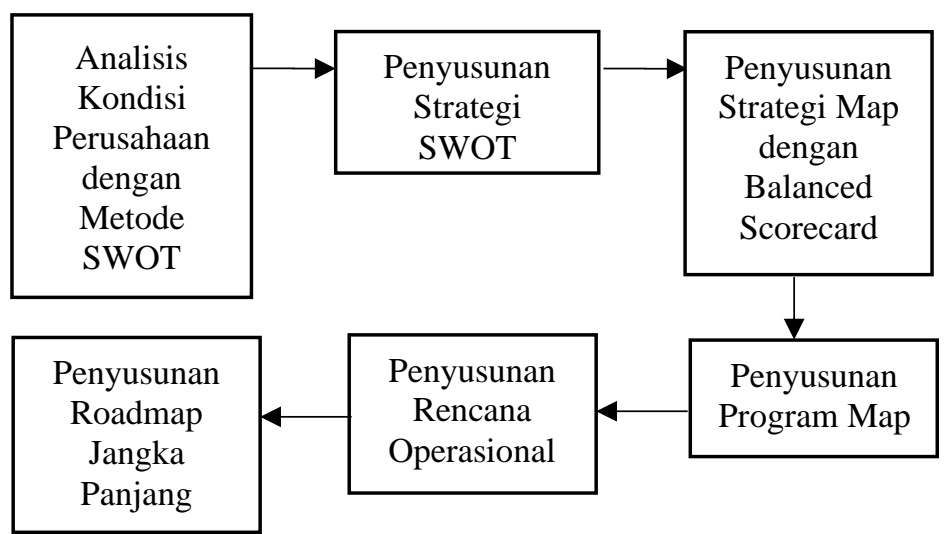

Gambar 2.2. Kerangka Konseptual 


\section{HASIL DAN PEMBAHASAN}

Penelitian ini menggunakan metode SWOT yaitu metode perencanaan strategis yang digunakan untuk mengevaluasi kekuatan (strengths), kelemahan (weaknesses), peluang (opportunities), dan acaman (threats) dalam suatu proyek atau spekulasi bisnis. Penelitian ini juga menggunakan metode Balanced Scorecard suatu metode untuk pengukuran dan penilaian kinerja suatu perusahaan dengan mengukur empat perpektif yaitu: Keuangan, pelanggan, proses bisnis internal, pembelajaran dan pertumbuhan. Hasil analisis SWOT menunjukkan bahwa perhitungan Matriks IFAS dan EFAS diperoleh hasil IFAS lebih tinggi daripada EFAS dan skor tertinggi terdapat pada Strengths sebesar 2,0667.

Penelitian mengenai pengembangan strategi pernah dilakukan oleh William F. Glueckdan Lawrence R Jauch, (2015). Strategi dikembangkan dengan menggunakan Metode SWOT. Tujuan yang diharapkan dari strategi tersebut adalah untuk merumuskan suatu trategi perusahaan, seorang manajer harus mengetahui kemampuan, keterbatasan dalam memilih strategi perusahaan. Strategi yang diusulkan yaitu untuk mimilih strategi tersebut yang andal, yang disesuaikan dengan peluang, ancaman, kekuatan, dan kelemahan perusahaan

\subsection{Strategi Analisis SWOT}

Strategi analisis SWOT dapat dilihat pada Gambar 3.1.

\begin{tabular}{|c|c|c|c|c|}
\hline & & & Strength (Kekuatan) & $\begin{array}{l}\text { Weakness } \\
\text { (Kelemahan) }\end{array}$ \\
\hline & & & $\begin{array}{l}\text { S1. Memiliki fasilitas free Wi-fi } \\
\text { dan full AC dalam melakukan } \\
\text { perjalanan. } \\
\text { S2. Memiliki driver yang bisa } \\
\text { pemandu objek wisata yang } \\
\text { berpengalaman. } \\
\text { S3. Memiliki tarif yang } \\
\text { ditawarkan kompetitif. } \\
\text { S4. Akses pasar terbuka lebar. } \\
\text { S5. Memiliki jaringan yang luas. }\end{array}$ & $\begin{array}{l}\text { W1. Perusahaan tidak } \\
\text { memiliki website. } \\
\text { W2. Kendaraan masih } \\
\text { minim. } \\
\text { W3. Belum ada standar } \\
\text { perawatan yang baik. } \\
\text { W4. Supir ugal-ugalan }\end{array}$ \\
\hline \multirow{2}{*}{ 预 } & 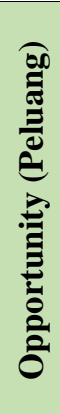 & $\begin{array}{l}\text { O1. Dapat merambat ke sektor } \\
\text { bisnis lainnya. } \\
\text { O2. Membuka lapangan } \\
\text { pekerjaan. } \\
\text { O3. Memiliki destinasi wisata } \\
\text { yang ada di Sumatara Utara. } \\
\text { O4. Pangsa pasar masih besar. } \\
\text { O5. Kebutuhan transportasi } \\
\text { semakin tinggi. }\end{array}$ & $\begin{array}{l}\text { 1. Mengembangkan bisnis travel. } \\
\text { SO2. Meningkatkan promosi. } \\
\text { SO3. Meningkatkan laba } \\
\text { SO4. Meningkatkan Kepuasan } \\
\text { Pelanggan }\end{array}$ & $\begin{array}{l}\text { WO1. Promosi melalui } \\
\text { jejaring. } \\
\text { WO2. Promosi online. }\end{array}$ \\
\hline & 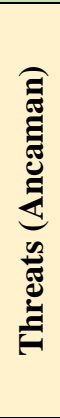 & $\begin{array}{l}\text { T1. Tingginya persaingan bisnis } \\
\text { transportasinya. } \\
\text { T2. Masuknya teknologi baru. } \\
\text { T3. Lonjakan penumpang yang } \\
\text { menurunkan quantity perusahaan. } \\
\text { T4. Adanya kecurangan dari } \\
\text { bisnis transportasi lainnya. } \\
\text { T5. Kurangnya kesadaran } \\
\text { masyarakat akan keselamatan. }\end{array}$ & $\begin{array}{l}\text { ST1. Mengembangkan } \\
\text { pelayanan. } \\
\text { ST2. Menawarkan promosi. }\end{array}$ & $\begin{array}{l}\text { WT1.Meningkatkan } \\
\text { Pelayanan Online. } \\
\text { WT2.Pengembangan } \\
\text { Sumber Daya Manusia. }\end{array}$ \\
\hline
\end{tabular}

Gambar 3.1. Strategi Analisis SWOT 


\subsection{Penyusunan strategi SWOT}

Penyusunan strategi SWOT dilakukan dengan menggunakan analisi IVAS (Internal Factor Analisis System) dan analisis EFAS (Eksternal Factor Analisis System). Adapun contoh perhitungan matriks IFAS dan EFAS sebagai berikut.

Tabel 3.2.1. Rekapitulasi IFAS dan EFAS

\begin{tabular}{|c|c|c|c|c|c|}
\hline & Pertanyaan & Nilai & Kepentingan & Bobot & Score \\
\hline \multirow{5}{*}{$\begin{array}{c} \\
\mathbf{S} \\
\mathbf{T} \\
\mathbf{R} \\
\mathbf{E} \\
\mathbf{N} \\
\mathbf{G} \\
\mathbf{H} \\
\mathbf{T}\end{array}$} & $\begin{array}{l}\text { S1. Memiliki fasilitas free Wi-fi } \\
\text { dan full AC dalam melakukan } \\
\text { perjalanan. }\end{array}$ & 4 & 4 & 0,1333 & 0,5333 \\
\hline & $\begin{array}{l}\text { S2. Memiliki driver yang bisa } \\
\text { pemandu objek wisata yang } \\
\text { berpengalaman. }\end{array}$ & 3 & 2 & 0,0667 & 0,2000 \\
\hline & $\begin{array}{l}\text { S3. Memiliki tarif yang ditawarkan } \\
\text { kompetitif. }\end{array}$ & 4 & 4 & 0,1333 & 0,5333 \\
\hline & S4. Akses pasar terbuka lebar. & 3 & 4 & 0,1333 & 0,4000 \\
\hline & S5. Memiliki jaringan yang luas. & 3 & 4 & 0,1333 & 0,4000 \\
\hline & & & & $\mathbf{0 , 6 0 0 0}$ & 2,0667 \\
\hline \multirow{6}{*}{$\begin{array}{l}\mathbf{W} \\
\mathbf{E} \\
\mathbf{A} \\
\mathbf{K} \\
\mathbf{N} \\
\mathbf{E} \\
\mathbf{S} \\
\mathbf{S}\end{array}$} & $\begin{array}{l}\text { W1. Perusahaan tidak memiliki } \\
\text { website. }\end{array}$ & 2 & 1 & 0,0333 & 0,0667 \\
\hline & W2. Kendaraan masih minim. & 3 & 4 & 0,1333 & 0,4000 \\
\hline & $\begin{array}{l}\text { W3. Belum ada standar perawatan } \\
\text { yang baik. }\end{array}$ & 3 & 3 & 0,1000 & 0,3000 \\
\hline & W4. Supir ugal-ugalan & 2 & 4 & 0,1333 & 0,2667 \\
\hline & \multicolumn{3}{|c|}{ SKOR PEMBAHASAN } & 0,4000 & 1,0333 \\
\hline & \multicolumn{3}{|c|}{ TOTAL SKOR IFE } & \multicolumn{2}{|c|}{3,1000} \\
\hline
\end{tabular}

Dengan menggunakan cara yang sama, seperti Strengts, perhitungan untuk Opportunities dan Threats direkapitulasi pada Tabel 2

Tabel 3.2.2. Rekapitulasi matriks IFAS dan EFAS

\begin{tabular}{|c|c|c|c|c|c|}
\hline & Pertanyaan & Nilai & Kepentingan & Bobot & Score \\
\hline \multirow{5}{*}{$\begin{array}{l}\mathbf{O} \\
\mathbf{P} \\
\mathbf{P} \\
\mathbf{O} \\
\mathbf{R} \\
\mathbf{T} \\
\mathbf{U} \\
\mathbf{I} \\
\mathbf{T} \\
\mathbf{Y}\end{array}$} & O1. Dapat merambat ke sektor bisnis lainnya. & 3 & 4 & 0,1026 & 0,3077 \\
\hline & O2. Membuka lapangan pekerjaan. & 3 & 4 & 0,1026 & 0,3077 \\
\hline & $\begin{array}{l}\text { O3. Memiliki destinasi wisata yang ada di } \\
\text { Sumatara Utara. }\end{array}$ & 4 & 4 & 0,1026 & 0,4103 \\
\hline & O4. Pangsa pasar masih besar. & 2 & 4 & 0,1026 & 0,2051 \\
\hline & O5. Kebutuhan transportasi semakin tinggi. & 3 & 4 & 0,1026 & 0,3077 \\
\hline \multirow{6}{*}{$\begin{array}{l}\text { T } \\
\mathbf{H} \\
\mathbf{R} \\
\mathbf{E} \\
\mathbf{A} \\
\mathbf{T} \\
\mathbf{S}\end{array}$} & & & & $\mathbf{0 , 5 1 2 8}$ & 1,5385 \\
\hline & T1. Tingginya persaingan bisnis transportasinya. & 3 & 4 & 0,1026 & 0,3077 \\
\hline & T2. Masuknya teknologi baru. & 3 & 4 & 0,1026 & 0,3077 \\
\hline & $\begin{array}{l}\text { T3. Lonjakan penumpang yang menurunkan } \\
\text { quantity perusahaan. }\end{array}$ & 2 & 4 & 0,1026 & 0,2051 \\
\hline & $\begin{array}{l}\text { T4. Adanya kecurangan dari bisnis transportasi } \\
\text { lainnya. }\end{array}$ & 3 & 3 & 0,0769 & 0,2308 \\
\hline & $\begin{array}{l}\text { T5. Kurangnya kesadaran masyarakat akan } \\
\text { keselamatan. }\end{array}$ & 3 & 4 & 0,1026 & 0,3077 \\
\hline & \multicolumn{3}{|l|}{ HASIL PEMBAHASAN } & 0,4872 & 1,3590 \\
\hline & \multicolumn{3}{|l|}{ TOTAL SKOR EFE } & \multicolumn{2}{|c|}{$\begin{array}{c}1 \\
28974\end{array}$} \\
\hline
\end{tabular}




\subsection{VMTS (Visi, Misi, Tujuan, dan Sasaran)}

UMKM (perusahaan) merupakan suatu organisasi atau suatu sistem yang terdiri dari berbagai unut-unit yang saling bekerja sama dalam mencapai tujuan organisasi. Organisasi tentunnya memiliki suatu peraturan yang di jalan kan bersama untuk mencapai suatu tujuan yang telah di tetapkan perusahaan, suatu perusahaan tidak terlepas dari suatu visi dan juga misi yang telah di tetapkan.

UMKM yang bergerak di bidang jasa transportasi yang menjadi objek penelitian ini memiliki visi dan misi organisasi meliputi:

\section{Visi} tahun 2025.

Menjadi perusahaan jasa transportasi yang terbaik, dan terpercaya di Sumatera Utara pada

\section{Misi}

Misi dapat dilihat di bawah ini:

1. Menjadi perusahaan layanan transportasi yang berkualitas untuk masyarakat.

2. Menjadi perusahaan yang lebih mengutamakan kenyaman dan keamanan dalam melakukan suatu perjalanan.

3. Meningkatkan pelayanan untuk customer.

\section{Tujuan}

Tujuan dapat dilihat di bawah ini:

1. Mengembangkan sumber daya manusia.

2. Lebih meningkatkan kualitas pelayanan transportasi.

3. Meningkatkan kenyaman customer.

4. Meningkatkan keamanan customer.

\section{Sasaran}

Target ukuran yang akan dicapai setelah 5 tahun

1. Menjadi perusahaan layanan 24 jam.

2. Lebih mengutamakan keselamatan para customer.

3. Meningkatkan ketersediaan sarana transportasi.

4. Melayani customer dengan sepunuh hati. 


\subsection{Pemetaan Posisi Perusahaan pada Matriks IFAS-EFAS}

Pemetaan Posisi Perusahaan pada Matriks IFAS-EFAS pada Gambar 3.4.

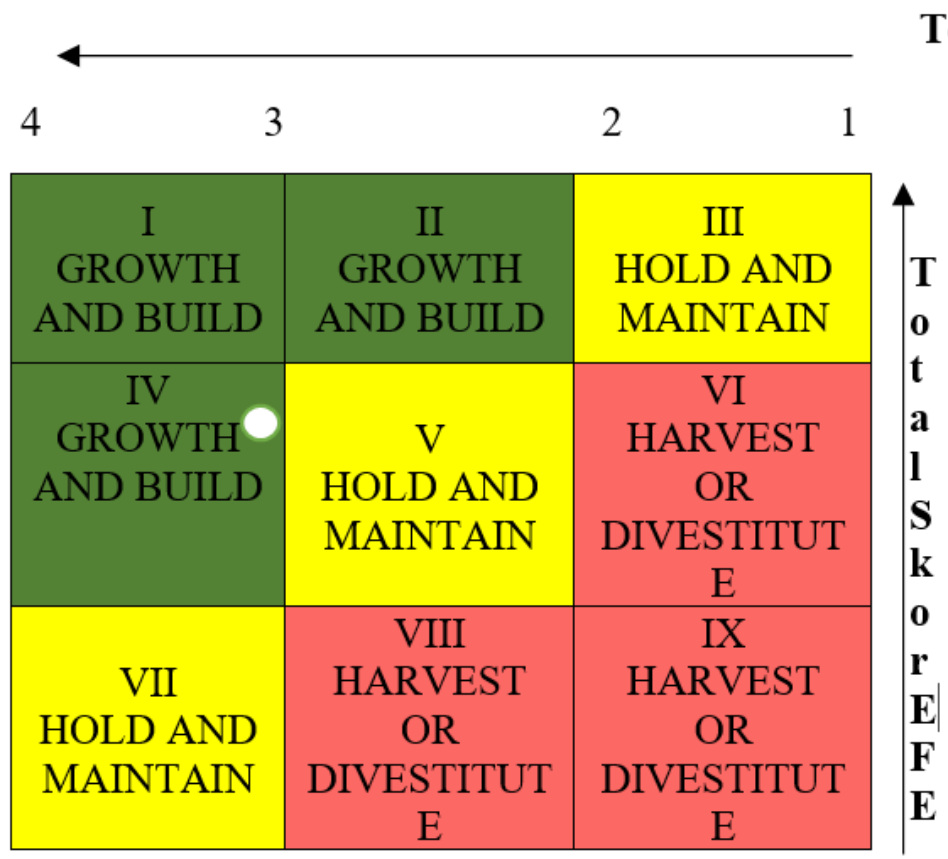

Total Skor IFE

Gambar 3.4. Pemetaan Posisi Perusahaan pada Matriks IFAS_EFAS

\section{KESIMPULAN}

Adapun kesimpulan yang diperoleh dari hasil penelitian tersebut adalah bahwa berdasarkan Matriks IFAS-EFAS, perusahaan berada pada kuadran I dan kuadran II (perusahaan memiliki kekuatan internal yang positif dan memiliki ancaman eksternal yang positif) yang artinya perusahaan harus mampu mempertahan kan dan meningkatkan kekuatan internal yang dimiliki perusahaan dan mengurangi ancaman external yang sedang dialami perusahaan untuk pencapaian tujuan perusahaan yang semakin membaik.

\subsection{Strategi perusahaan dalam mengatasi permasalahan}

Strategi perusahaan dalam meningkatkan perusahaan sebagai berikut:

1. Membagi-bagikan brosur dengan memanfaatkan media sosial.

2. Memasukkan brosur kedalam situs google yang dapat dilihat oleh banyak orang.

3. Membagikan brosur secara langsung. Mengumpulkan data yang menjadi keluhan pelanggan

4. Mengidentifikasi data yang di butuhkan untuk menemukan pelanggan yang ingin menggunakan UMKM jasa transportasi di perusahaan.

5. Melakukan pelatihan dalam meningkatkan kualitas para pekerja untuk mendapatkan laba perusahaan.

6. Menggembangkan sumber daya manusia melalui pendidikan dapat dilakukan dengan meningkatkan kemampuan kerja, dalam arti pengembangan yang bersifat formal dan berkaitan pada karir mereka.

\section{REFERENSI}

Amirullah. PengantarManajemen/ Amirullah -Jakarta: MitraWancana Media, 2015, 1 jil.,17x 24 cm, 264 hal. 
Abdurrahman, Herdiana, Nana. Maret 2015. Manajemen Strategi Pemasaran. Bandung: PustakaSetia.

Assauri, Sofjan. Manajemen Pemasaran. Jakarta: Rajawali Pers, 2015

Gaspersz. Vincent. September 2000, Manajemen Produktivitas Total, Strategi Peningkatan Produktivitas Bisnis Global : Jakarta

Gultom, D. K. (2017). Pengaruh bauran pemasaran jasa terhadap citra destinasi dan kepuasan wisatawan serta implikasinya terhadap loyalitas wisatawan.

Jauch, Lawrence R. (2015). Jakarta: Erlangga. Strategi Management and business policy.

Jurnal Riset Sains Manajemen, 1(2), 139-150 Retrieved http://ejurnal.id/index.php/jsm/article/view/103

Tahaka. C. Y. (2013). Penerapan Balanced Scorecard Sebagai Alat Ukur Kinerja pada PT. Bank Sulut. Skripsi. Universitas Sam Ratulangi Manado.

Prawita. B. D. (2017). Strategi Bisnis Pada Success Mobil Melalui Pendekatan Analisis Swot. Skripsi. Universitas Kristen Petra.

Fatahillah. Fuad. (2017). Perencanaan Strategi Perusahaan Dengan Balance Scorecard pada PT. XYZ. Skripsi. Universitas Mercu Buana. Jakarta.

Wheelen, Thomas L. Hunger, David. Pearson Education Limited, 2017. Strategic Management and Bussiness Policy: Globalization, Innovation and Sustainability, Global Edition. 